\title{
The Architecture of Learning Object Repositories
}

\author{
Ismar Frango Silveira, Nizam Omar, \\ and Pollyana Notargiacomo Mustaro \\ Universidade Presbiteriana Mackenzie - Sao Paulo, SP, Brazil
}

\author{
ismar@mackenzie.br omar@mackenzie.br \\ polly@mackenzie.br
}

\begin{abstract}
The definition used for learning objects considers them as any digital entity which can be used, reused or referenced during a technology-mediated learning process. Nowadays, this concept has became essential to the development of pedagogical content to be used in large scale educational projects to which are engaged a wide number of educational agents - students, teachers and faculty staff. Guaranteeing reusability of pedagogical content allows its use on different contexts. Therefore, a repository of learning objects that has a well-defined metadata structure can be used to customize learning processes. Recent researches on Learning Object have been contributing on the search of patterns for instructional content development, in order to make them adaptive, generic, portable and scalable enough to improve their potential for reusability. Besides, a wide range of virtual learning environments has been proposed to support these learning objects, with their properties and characteristics. Nonetheless, the great challenge still remains on how adaptive can a learning object be.

There are several levels of adaptation that can be reached, and these levels can be established regarding to a wide range of different aspects on teaching-learning processes, varying from the need of keeping track of students' evolution on building a specified piece of desired knowledge, until their learning styles, a multi-dimensional measure that are not only individual-dependant, but are also influenced by a range of factors so diverse as environment, inter-relational issues and psychological aspects related to how a student deal with certain sort of knowledge to be constructed, or skill to be developed.
\end{abstract}

An architecture for learning objects repositories that intends to be general enough to support different pedagogical approaches and adaptation levels is presented. Such architecture is based on five different but co-related tiers: Syllabus Tier, which encapsulates all organization of learning objects that persist on the Reusable Learning Objects Tier. To select and present these objects in a way that adaptation to students' background, learning styles and temporal motivation is responsibility of Apprentice Model Tier and Learning Styles Tier, that together drive Presentation Tier to dynamically built the most adequate interface to each student. Therefore, multiple presentations for the same learning object can make learning process more significant to students.

Material published as part of these proceedings, either on-line or in print, is copyrighted by Informing Science. Permission to make digital or paper copy of part or all of these works for personal or classroom use is granted without fee provided that the copies are not made or distributed for profit or commercial advantage AND that copies 1) bear this notice in full and 2) give the full citation on the first page. It is permissible to abstract these works so long as credit is given. To copy in all other cases or to republish or to post on a server or to redistribute to lists requires specific permission from the publisher at Publisher@InformingScience.org
This kind of architecture can be empowered by applying it on collaborative systems, when a possible lack of an adequate implementation of some learning object would not be a fence to the learning process, since it would be reachable through collaboration. Even when the nature of a learning object makes it not adequate to pro- 
Granularity of Learning Objects

mote the building of some sort of knowledge, collaboration can provide the means for supplement what lacks on learning object, helping to build new kinds of knowledge, and consequently acting to aid skills' development. 